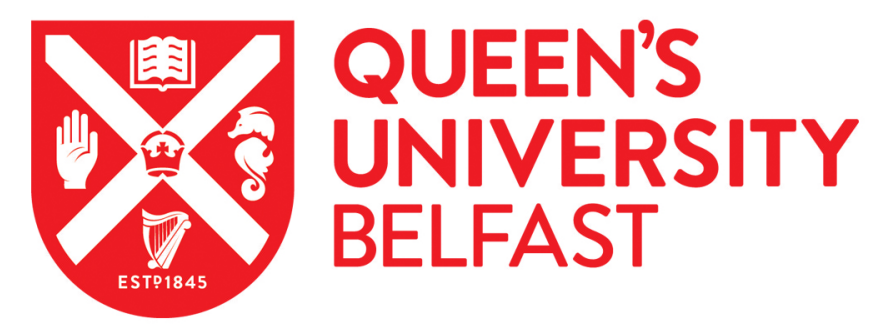

\title{
Solidarity and Territorial Boundaries in a Transnational Context: the Case of Cross-Border Movement of Patients
}

Rieder, C. M. (2019). Solidarity and Territorial Boundaries in a Transnational Context: the Case of Cross-Border Movement of Patients. Transnational Legal Theory, 10(2), 163-183 .

https://doi.org/10.1080/20414005.2019.1614361

\section{Published in:}

Transnational Legal Theory

Document Version:

Peer reviewed version

Queen's University Belfast - Research Portal:

Link to publication record in Queen's University Belfast Research Portal

Publisher rights

(C) 2019 Informa UK Limited, trading as Taylor \& Francis Group. This work is made available online in accordance with the publisher's policies. Please refer to any applicable terms of use of the publisher.

\section{General rights}

Copyright for the publications made accessible via the Queen's University Belfast Research Portal is retained by the author(s) and / or other copyright owners and it is a condition of accessing these publications that users recognise and abide by the legal requirements associated with these rights.

Take down policy

The Research Portal is Queen's institutional repository that provides access to Queen's research output. Every effort has been made to ensure that content in the Research Portal does not infringe any person's rights, or applicable UK laws. If you discover content in the Research Portal that you believe breaches copyright or violates any law, please contact openaccess@qub.ac.uk. 


\title{
Solidarity and Territorial Boundaries in a Transnational Context: the Case of Cross-Border Movement of Patients
}

\author{
Dr Clemens M Rieder \\ Lecturer, Queens' University Belfast ${ }^{1}$
}

This article examines the relationship between solidarity and territorial boundaries, both of which are critical focal points in relation to the process of European integration. With that focus on boundaries and solidarity, the article will take a fresh look at cross-border movement of patients by conceptualising the field in a more abstract and theoretical manner which aims to be of value in relation to welfare systems in general. In particular, the article will examine the role of free movement and human rights as instruments for overcoming territorial boundaries. The degree of impact these rights have on boundaries and consequently on solidarity, by virtue of the authority they convey, is largely determined by the underlying principles, namely efficiency and dignity, which constitute the normative basis of these rights.

One of the defining characteristics of the Westphalian system has been that the modern notion of "territory" is inextricably linked to the rights of jurisdictional authority over a territorial or geographical domain, and so is a profoundly political notion'. ${ }^{2}$ A pivotal aim of the single market is to call this established system into question and create another 'single space' ${ }^{3}$ This process has both a territorial and a membership dimension. To what extent the 'territorial masters [have been] losing control of their own borders' as a consequence of European integration remains a contested question. ${ }^{4} \mathrm{I}$ am interested in this question with regard to solidarity and will use cross-border movement of patients, which has been linked closely to the principle of territoriality, as a paradigmatic example. ${ }^{5}$

\footnotetext{
${ }^{1}$ I am grateful to Professor Chris Hilson, Professor Gordon Anthony, Professor Chris McCrudden and the anonymous reviewers of this journal for their helpful comments on earlier drafts; all errors remain mine.

${ }^{2}$ M Moore, A Political Theory of Territory (OUP 2015) 15.

${ }^{3} \mathrm{~S}$ Weatherill, The Internal Market as a Legal Concept (OUP 2017) 3.

${ }^{4}$ J Habermas, 'The Postnational Constellation and the Future of Democracy' in M Pensky (ed and tr) The Postnational Constellation. Political Essays (Polity 2007) 58, 80.

${ }^{5} \mathrm{~W}$ Palm and IA Glinos, 'Enabling patient mobility in the EU: between free movement and coordination' in E Mossialos and others (eds) Health Systems Governance in Europe. The Role of European Union Law and Policy
} 
Curiously, the academic literature on solidarity in the EU, has failed to take boundaries seriously. This article is an attempt to remedy this important gap in the debate. The starting point for my argument is that territorial boundaries protect the quantity of national solidarity, whereas membership boundaries have a relationship with the quality of solidarity. Only when the integrity of membership boundaries is called into question does supranational solidarity - that is, a change in the quality of solidarity - become possible. I will not discuss this aspect of solidarity in this article, however. Instead, I will question the integrity of territorial boundaries, which is conceptually linked to the quantity of national solidarity.

I then will examine the relationship between supranational law and boundaries through the prism of rights. The focus on rights, it seems to me, is justified for at least two reasons. First, the internal market has been created largely through free movement rights. ${ }^{6}$ Second, rights play an increasingly important role in relation to governing. ${ }^{7}$ Rather than a detailed doctrinal analysis, this article engages in the studying of the principles which may serve as a justification for these rights and their effects. ${ }^{8}$ In particular, I will draw on two principles, namely efficiency and dignity, which I will argue are differentiated by the nature of their authority. While efficiency is somewhat closely related to free movement rights, dignity has a manifold relationship with human rights. Finally, I will examine whether the dimension of EU citizenship has had any implications for the interpretation of free movement rights or human rights.

(CUP 2010) 509; AJ Obermaier, The End of Territoriality? The Impact of ECJ Rulings on British, German and French Social Policy (Ashgate 2009) passim.

${ }^{6} \mathrm{~F}$ Scharpf, Governing in Europe. Effective and Democratic? (OUP 1990) 50-52.

${ }^{7}$ B Sokhi-Bulley, Governing (Through) Rights (Hart Publishing 2016) 4.

${ }^{8}$ R Alexy, A Theory of Constitutional Rights (J Rivers tr, OUP 2010) 59. 


\section{Rights}

To claim that boundaries matter when it comes to solidarity is not particularly controversial. ${ }^{9}$ Therefore, it will not come as a surprise that the questioning of existing boundaries is highly contentious because it threatens the social status and has the potential to destabilise a society. After all, even among Member States of the EU, boundaries still largely determine the wealth, education and health care a person receives. ${ }^{10}$ In some ways, boundaries constitute a dichotomy: they point to 'the heart of conflict' but at the same time facilitate coexistence. ${ }^{11}$ Similarly, while rights can be used to draw or reinforce boundaries, ${ }^{12}$ they also can help to overcome boundaries. Here I am interested in the latter. The close relationship between rights and boundaries may be but one explanation for why rights are sometimes considered political.

However, in discussions about solidarity in the EU context the focus is often exclusively on rights, while the role of boundaries is ignored. In order to conceptualise the role of boundaries in relation to solidarity it is important to clearly differentiate between territorial and membership boundaries. A comparison between health care and education in the European context will clarify my point. Arguably, one would expect similar treatment under EU law of health care and education because both fields constitute public services for which 'many of the same arguments apply'. ${ }^{13}$ However, the European Court of Justice (ECJ)

\footnotetext{
${ }^{9}$ M Ferrera, The Boundaries of Welfare. European Integration and the New Spatial Politics of Social Protection (OUP 2005) 2.

${ }^{10}$ A Buchanan and M Moore, 'Introduction: The Making and Unmaking of Boundaries', in A Buchanan and M Moore (eds) States, Nations and Borders. The Ethics of Making Boundaries (CUP 2003) 1.

${ }^{11}$ A Hurrell, 'International Law and the Making and Unmaking of Boundaries' in A Buchanan and M Moore (eds) States, Nations, and Border. The Ethics of Making Boundaries (CUP 2003) 275, 278-279.

12 J Nedelsky, 'Law, Boundaries, and the Bounded Self' (1990) 30 Representations: Law and the Order of Culture 162, 167.

${ }^{13} \mathrm{~J}$ Le Grand, The Other Invisible Hand: Delivering Public Services through Choice and Competition (Princeton UP 2007) 96.
} 
decided to treat them differently. Accordingly, and in contrast to health care, ${ }^{14}$ the Court concluded that public education falls outside the application of the Treaty. ${ }^{15}$ In other words, in relation to health care the right to free movement of services was applicable, whereas for education it was not. This diverging approach, which seems to me to be a consequence of focusing exclusively on rights instead of boundaries and rights, has been criticised by some.

Somek, for example, has argued that, because of the role of solidarity in education and public health care, the ECJ should have pursued the same approach towards both and decided that health care, like education, is beyond the reach of the Treaty. ${ }^{16}$ Hervey considers solidarity generally to be 'a buttress against market law'. ${ }^{17}$ Taking a slightly different focus, Shuibhne makes the point that the two strands of case law, education and health care, are not only conflicting but evidence of the Court's 'incompleteness of reasoning and the selective citation of existing authority'. ${ }^{18}$ Davies, on the other hand, makes an elaborate attempt to remedy the Court's approach by distinguishing education from health care based on techniques of statutory interpretation. ${ }^{19}$ However, none of these arguments, it seems to me, are ultimately convincing.

Instead, I want to recognize that European integration is a massive 'operation of boundary redrawing, ${ }^{20}$ or 'redefinition' ${ }^{21}$ which finds its expression in Article 26.2 of the

\footnotetext{
${ }^{14}$ Case C-158/96 Raymond Kohll v Union des Caisses de Maladie [1998] ECR I-1931, para 29.

${ }^{15}$ Case 263/86 Belgian State v René Humbel and Marie-Thérèse Humbel née Edel [1988] ECR 05365, para 20.

${ }^{16}$ A Somek, 'Solidarity Decomposed: Being and Time in European Citizenship' (2007) 32 European Law Review 787, 788-789.

${ }^{17}$ TK Hervey, 'Social Solidarity: a Buttress against Internal Market Law' in J Shaw (ed), Social Law and Policy in an Evolving European Union (Hart Publishing 2000) 31-47.

${ }^{18}$ NN Shuibhne, The Coherence of EU Free Movement Law. Constitutional Responsibility and the Court of Justice (OUP 2013) 66.

${ }^{19}$ G Davies, 'The Process and Side-Effects of Harmonisation of European Welfare States' (2006) 02/06 Jean Monnet Working Paper Series 15-17 < http://jeanmonnetprogram.org/wp-content/uploads/2014/12/060201.pdf> accessed 28 September 2018.

${ }^{20}$ Ferrera (n 9) 3.

${ }^{21}$ S Bartolini, Restructuring Europe: Centre Formation, System Building and Political Structuring between the Nation-State and the European Union (OUP 2005) xiii.
} 
Treaty on the Functioning of the European Union (TFEU), which states that ' $[\mathrm{t}] \mathrm{he}$ internal market shall comprise an area without internal frontiers in which the free movement of goods, persons, services and capital is ensured'. ${ }^{22}$ The market constitutes a 'geographical space, 23 and the process amounts to an attack on the sovereignty of Member States. In particular, free movement rights have played an important role in overcoming boundaries and fostering negative integration. ${ }^{24}$ In addition, human rights also present a challenge to boundaries in that they 'extend across political and social boundaries. ${ }^{25}$ Somewhat in the background looms the important question of the extent to which the concept of EU citizenship has influenced the effects of free movement rights and human rights on boundaries.

Because rights will play an important role in the following debate, it only seems natural to outline their grammar in more detail. My discussion begins with an analysis of their form. While reflecting on the form of rights does not help to solve problems arising from questions of social justice, it is a useful way to 'to define and clarify' the issues at stake and ideally help us to come to 'an informed and sound conclusion'. ${ }^{26}$ In other words, the exercise will improve our understanding of what it means to say that a person has a specific right to something. Reflecting on the form of rights will give us a better understanding of the different facets involved in the simple statement that a person has a specific right to something. ${ }^{27}$ From the outset, I should note that the reference to 'rights' is not limited to legal rights stricto sensu but also includes moral and conventional 'rights'. ${ }^{28}$

\footnotetext{
22 Emphasis added.

${ }^{23}$ Bartolini (n 21) 73.

24 ibid 178.

${ }^{25}$ CR Beitz, The Idea of Human Rights (OUP 2009) 1.

${ }^{26}$ AL Corbin, 'Foreword' in WN Hohfeld, Fundamental Legal Conceptions as Applied Judicial Reasons (Yale UP 1964) xi.

${ }^{27} \mathrm{~J}$ Waldron, 'Introduction' in J Waldron (ed), Theories of Rights (OUP 1995) 1, 5.

${ }^{28}$ L Wenar, 'The Nature of Rights' (2005) 33 Philosophy and Public Affairs 223, 230.
} 
In the subsequent discussion, I want to draw on Hohfeld's taxonomy of rights, which famously distinguished between rights, privileges, powers and immunities. ${ }^{29}$ For the purposes of this article, I will draw particularly on two of Hohfeld's categories: rights and powers. A claim right, as understood by Hohfeld, can be compared with an individual right. ${ }^{30}$ 'A has a Y right that $\mathrm{B} \varphi$ ' implies that ' $\mathrm{B}$ has a $\mathrm{Y}$ duty to $\mathrm{A}$ to $\varphi$ '. ${ }^{31}$ Thus Hohfeld's claim rights must correlate with duties. ${ }^{32}$ The importance of duties in relation to rights was also emphasised by O'Neill, who has argued that '[w]hen we try to be definite about rights, we always have to talk about obligations'. ${ }^{33}$ It is often argued that an important exemplary application of claim rights are contracts, because contractual relationships typically consist of a correlation between rights and duties. ${ }^{34}$ Thus, the substance of a claim right is determined by an existing obligation. For example, an employee has a claim right to be paid wages. Finally, for the purposes of this article, a contract not only refers to a contractual relationship between two or more individuals but also encompasses the idea of a social contract.

By contrast, power rights are higher-order rights, which allow for the alteration of lower-order rights such as claim rights themselves. ${ }^{35}$ This can be expressed as follows: 'A has a right to $\varphi,{ }^{36}$ Power rights vest their holder with the ability to change a normative situation for themselves or another person. ${ }^{37}$ In other words, they give an individual the power 'to alter existing legal arrangements', ${ }^{38}$ they can change existing obligations. ${ }^{39}$ In the context of this article, this means that power rights confer the authority to change solidarity, which is an

\footnotetext{
${ }^{29}$ WN Hohfeld, Fundamental Legal Conceptions as Applied Judicial Reasons (Yale UP 1964) 36.

${ }^{30}$ Waldron (n 26) 8

${ }^{31}$ Wenar (n 27) 230 (emphasis added).

${ }^{32}$ Hohfeld (n 28) 38.

${ }^{33}$ O O'Neill, Justice Across Boundaries. Whose Obligations (CUP 2016) 38.

${ }^{34}$ Waldron (n 26) 6.

${ }^{35}$ Wenar (n 27) 233.

36 ibid 231.

37 ibid.

${ }^{38}$ Waldron (n 26) 7.

${ }^{39}$ GW Rainbolt, 'Rights Theory' (2006) 1 Philosophy Compass 11, 12.
} 
expression of a duty of some sort. This suggests that claim rights and power rights are subject to different forms of authority. It is to the concept of authority that the focus now shifts.

The importance of authority stems from the justification it provides as to why A has a duty to obey $\mathrm{B}^{40}$ My argument is based on the premise that there are different types of authority. ${ }^{41}$ These authorities, I will argue, are differentiated by the degree of their power to alter existing duties. What I mean by this may not be immediately obvious because power and authority are often falsely conflated. ${ }^{42}$ Often, in discussions about the relationship between authority and power, power is understood as a back-up for authority. In other words, power serves as a sanctioning mechanism. ${ }^{43}$ However, this is not the kind of relationship between power and authority with which I am concerned in this article.

Instead, I will focus on authority which has 'a contingent or conditional relation with power under the hood or bonnet of the car and authority in the driver's seat [. . .]. Authority is a warrant or licence - an authorization - to exercise power' ${ }^{44}$ To clarify my point, imagine a person driving a Porsche on a motorway with a speed limit of $130 \mathrm{~km} / \mathrm{h}$. The Porsche easily reaches $130 \mathrm{~km} / \mathrm{h}$. Thus, we can say that the authority of the driver and the power of the car coincide. ${ }^{45}$ By contrast, imagine someone driving on the same stretch of the motorway in an old VW Beatle which can barely reach $90 \mathrm{~km} / \mathrm{h}$. The driver has authority to drive $130 \mathrm{~km} / \mathrm{h}$ but the power of the car allows the driver to go only $90 \mathrm{~km} / \mathrm{h}$. In other words, while the driver of the Porsche enjoys auctorita perfecta, because authority and power match, the driver of the VW Beatle has only auctorita imperfecta, because authority and power do not coincide.

\footnotetext{
40 cf J Raz, The Morality of Freedom (OUP 1986) 23.

${ }^{41}$ A Somek, Individualism: An Essay on the Authority of the European Union (OUP 2008) 1.

${ }^{42}$ R Jackson, Sovereignty: The Evolution of an Idea (Polity 2007) 14.

${ }^{43}$ R Bierstedt, 'An Analysis of Social Power' (1950) 15 American Sociological Review 730, 736.

44 Jackson (n 41) 14.

${ }^{45}$ Arendt endorses the separation of power and authority by referring back to the Romans who believed in potestas in populo and auctoritas in senatu. See H Arendt, On Revolution (Penguin Classics 2006) 191.
} 
As this example indicates, power influences the type of authority we have. Arguably, authority with power (auctorita perfecta) allows the supranational level to alter existing obligations (solidarity), enabling existing boundaries to be altered. This type of authority finds its expression through power rights. By contrast, authority without power (auctorita imperfecta) does not permit changes to existing obligations. Consequently, boundaries can only be altered to the extent that doing so has no effect on existing obligations, that is, solidarity.

So far, I have sought to establish that there are not only different forms of rights but also different types of authority and to show how they interconnect. I now want to establish what form of rights and type of authority are embodied in the right to free movement of services and in human rights. In developing this argument, I will draw on two principles: efficiency and dignity. These principles are paradigmatic because they resemble two essential pillars on which the authority of the EU is based. As Walker argues, 'many narratives of the European Union [. . . ] began from the economic core'. ${ }^{46}$ The 'economic core' makes a link to the principle of efficiency plausible. More tangible, it seems to me, is the claim that the justification for the common market should rest not only on the objective of wealth maximisation but also on the principle of dignity. ${ }^{47}$ There is a growing understanding that the EU needs to develop its 'human face' 48 if it wants to survive.

In my analysis of the relationship between boundaries and rights, my initial focus will be on free movement rights, whose primary function, I would argue, is to build an internal market by removing any existing obstacles between Member States. Their authority is closely

\footnotetext{
${ }^{46}$ N Walker, 'The Philosophy of European Union Law' (2014) Europa Working Paper No 2014/06; Edinburgh School of Law Research Paper No. 2014/29, 9.

$47 \mathrm{cf} \mathrm{JHH}$ Weiler, The Constitution of Europe (OUP 1999) 244-246.

${ }^{48}$ See cf D Kostakopoulou, 'Conclusion: Towards a Humanistic Philosophy of the European Union' in N Ferreira and D Kostakopoulou (eds), The Human Face of the European Union. Are EU Law and Policy Humane Enough? (CUP 2016) ch 16.
} 
related to their function, which is to build an internal market based on efficiency. I aim to show that the Court's legal reasoning is based on the principle of Pareto Efficiency, which, I will argue, constitutes an embodiment of auctorita imperfecta. ${ }^{49}$ In other words, free movement rights take the form of claim rights which, as argued above, have no power to change existing solidarity. Consequently, the right to free movement of services can only have an impact on the integrity of boundaries to the extent that the quantity of national solidarity remains unchanged.

Following a brief excursion to examine what if any effect EU citizenship has an on the interpretation of free movement rights, focus of discussion will then shift to dignity, which is an important parameter in creating a 'decent society'. ${ }^{50}$ The specific question I wish to pursue is what kind of authority is linked to dignity. To address this question, it is important to capture the essence of dignity. Like Waldron, for whom dignity 'involves an upwards equalization of rank', ${ }^{51}$ I interpret dignity as a 'status-term'. ${ }^{52}$ In other words, dignity affects how we treat people within a given community.

Just as citizenship may be one way of 'realizing' human dignity, ${ }^{53}$ it could be argued that human rights are one way to protect human dignity. Yet what kind of authority is conveyed through dignity? If one accepts that dignity 'involves an upwards equalization of rank', then rights, in order to effectively protect dignity, must have the power to change existing obligations. In other words, dignity conveys auctorita perfecta. Furthermore, to the extent that human rights are linked to dignity, they share this type of authority. Inevitably, the discussion will become more speculative now because - apart from a brief excursion from

\footnotetext{
${ }^{49}$ A Buchanan, Ethics, Efficiency and the Market (Rowman \& Littlefield 1988) ch 1.

${ }^{50}$ A Margalit, The Decent Society (N Goldblum tr, Harvard UP 1996) 43-44.

${ }^{51} \mathrm{~J}$ Waldron, Dignity, Rank, and Rights (OUP 2009) 33.

52 ibid Lecture 1.

${ }^{53}$ J Waldron, 'Citizenship and Dignity', in C McCrudden (ed), Understanding Dignity (OUP 2013) $327,336$.
} 
Advocate General Colomer in Stamatelaki ${ }^{54}$ - there is no EU case law with which to test these conceptualisations.

\section{Efficiency}

Unsurprisingly, the Court has received both praise and criticism for its approach in linking health care with free movement law. In this section, I aim to provide a novel conceptualisation of ECJ case law, which has meaning beyond the field of health care. In particular, I will argue that the Court's reasoning has been based on the principle of Pareto efficiency. As is well known, a system is Pareto optimal if there is no alternative state of that system in which at least one person is better off while no one is worse off. A state $\left(\mathrm{S}_{1}\right)$ is Pareto superior to another state $\left(\mathrm{S}_{2}\right)$ if at least one person is better off in $\mathrm{S}_{1}$ than in $\mathrm{S}_{2}$ but nobody is worse off because of that change. ${ }^{55}$

While the principle of Pareto efficiency does not tell us whether a system is just or fair, ${ }^{56}$ its application is nevertheless justifiable in the context of internal market building because Pareto optimality and superiority are important ways to measure and improve the efficiency of a market. ${ }^{57}$ That said, it would appear that Pareto superiority mandates efficiency only of a restricted nature. The argument of efficiency is based on consequentialism. However, Pareto efficiency ignores the obvious problem related with utilitarianism, a form of

\footnotetext{
${ }^{54}$ Opinion of Advocate General Colomer in Case C-444/05, Aikaterini Stamatelaki v NPDD Organismos Asfaliseos Eleftheron Epangelmation (OAEE) [2007] ECR I-03185, para 40.

${ }_{55}$ A Buchanan, Ethics, Efficiency and the Market (Rowman \& Littlefield 1988) 4.

56 ibid 9-10.

${ }^{57} \mathrm{cf}$ M Poiares Maduro, We, the Court. The European Court of Justice and the European Economic Constitution (Hart 1998) 150-153.
} 
consequentialism, which makes the latter a contentious concept because it is based on 'interpersonal utility comparisons'. ${ }^{58}$

Arguably, Pareto efficiency does not confer the type of authority that comes with the power to change existing duties. In other words, Pareto efficiency only conveys auctorita imperfecta. Thus, boundaries can be changed as long as to do so has no impact on existing duties. The restrictive nature of Pareto efficiency has been criticised for being too demanding because 'almost no social decision [can] be justified'. ${ }^{59}$ Yet I will show that despite the stringency of the criterion, the ECJ has woven these ideals through the case law on health care. Whether the case law sustains empirical testing is, however, an altogether different question.

Before I test my hypothesis, I briefly want to categorise the form of free movement of services rights, which brings me back to Hohfeld. Applying Hohfeld's taxonomy, I will show that supranational free movement rights, in the context of health care, constitute claim rights. Accordingly, if A has a supranational right, then patient 'A has a $\mathrm{Y}$ right that the collective $\mathrm{B}$ $\varphi$ ', which implies that 'the collective B has a Y national duty to A to $\varphi$ '. In relation to claim rights, a duty can be either negative or positive. Whereas a negative duty implies that B must not impede A, a positive duty amounts to a requirement to provide assistance, ${ }^{60}$ which can constitute solidarity. However, claim rights do not have the power to alter the underlying metaphysical contract, therefore the duty as such, i.e. the quantity of national solidarity, remains fixed. In other words, the supranational level which provides the claim right does not have the type of authority necessary to change the national social contract.

\footnotetext{
${ }^{58}$ Buchanan (n 49) 7; for further thoughts on the relationship between Pareto superiority in utilitarianism, see JL Coleman, 'Efficiency, Utility, and Wealth Maximization' (1979-1980) 8 Hofstra Law Review 509, 515.

${ }^{59}$ R Dworkin, 'Why Efficiency? A Response to Professor Calabresi and Posner' (1980) 8 Hofstra Law Review $563,582$.

60 Waldron (n 26) 6.
} 
The EU legal framework outlines specific grounds on which patients are entitled to exit their home system, overcome the principle of territoriality and receive treatment in another Member State, paid for by their own system of affiliation. In the early days of European integration, Regulation No $3^{61}$ and No $4^{62}$ governed the terms and conditions under which patients were allowed to exit their home system. In fact, these regulations were among the first secondary laws ever passed in the European Economic Community. ${ }^{63}$ Eventually these two early regulations were superseded by Regulation No $1408 / 71^{64}$ and implementing Regulation No 574/72. ${ }^{65}$ Both were amended numerous times before they were finally replaced in 2010 by Regulation No 883/2004 ${ }^{66}$ and implementing Regulation No 987/2009. ${ }^{67}$ One core feature of the Regulation No $883 / 2004$ is that patients must request prior authorisation from the competent national authority before they can exit their home system and receive treatment in another Member State.

In the two Pierik cases, ${ }^{68}$ the Court interpreted a predecessor version of Article 20 Regulation No 883/2004, that is, Article 22.2 Regulation No $1408 / 71,{ }^{69}$ which stipulated that

\footnotetext{
${ }^{61}$ Verordnung Nr 3/58 (EWG) vom 16. Dezember 1958 über die Soziale Sicherheit von Wanderarbeitnehmern (ABl. 1958, 30/561, text available only in DE, FR, IT, NL).

${ }^{62}$ Verordnung Nr 4/58 (EWG) vom 16. Dezember 1958 zur Durchführung und Ergänzung der Verordnung Nr. 3 über die Soziale Sicherheit der Wanderarbeitnehmer (AB1. 1958, 30/597, text available only in DE, FR, IT, NL). ${ }^{63}$ M Fuchs, 'Free Movement of Services and Social Security - Quo Vadis?' (2002) 8 European Law Journal $536,545$.

${ }^{64}$ Regulation (EEC) No 1408/71 of the Council of 14 June 1971 on the Application of Social Security Schemes to Employed Persons and their Families Moving within the Community, English Special Edition: Series I ch 1971(II) 416, as amended.

${ }^{65}$ Regulation (EEC) No 574/72 of the Council of 21 March 1972 fixing the procedure for implementing Regulation (EEC) No 1408/71 on the application of social security schemes to employed persons and their families moving within the Community (English special edition: Series I ch 1972(I), 159).

${ }^{66}$ Corrigendum to Regulation (EC) No 883/2004/EC of the European Parliament and of the Council of 29 April 2004 on the coordination of social security systems [2004] OJ 2004 L166/1 (as amended).

${ }^{67}$ Regulation (EC) No 987/2009 of the European Parliament and of the Council of 16 September 2009, laying down the procedure for implementing Regulation (EC) No 883/2004 on the coordination of social security systems [2009] OJ L284/1).

${ }^{68}$ Case 117/77 Bestuur van het Algemeen Ziekenfonds Drenthe-Platteland v G Pierik [1978] ECR 825; Case 182/78, Bestuur van het Algemeen Ziekenfonds Drenthe-Platteland v G Pierik (No 2) ECR [1979] 1977.

${ }^{69}$ Regulation (EEC) No 1408/71 of the Council of 14 June 1971 on the Application of Social Security Schemes to Employed Persons and their Families Moving within the Community, English Special Edition: Series I ch 1971(II) 416.
} 
'[t]he authorisation required [...] may not be refused where the treatment in question cannot be provided for the person concerned within the territory of the Member State in which he resides'. The ECJ argued that the norm would cover two scenarios: in the first, treatment which is provided in the destination state is "more effective" ${ }^{\text {"70 }}$ than that which is available in the person's home state; in the second, a particular treatment is unavailable in the home state altogether. One consequence of the Court's intervention was that patients were given access to the best treatment available in Europe, which had considerable impact not only on territorial boundaries but also on the quantity of national solidarity.

It can be argued that the Court exercised auctorita perfecta by virtue of secondary law. In other words, the Court assumed the power to alter existing obligations. Unusually, however, Member States responded directly to the Court's ruling by amending Article 22 of Regulation 1408/71. They added two criteria, the primary aim of which was to regulate the impact the health care framework of the EU had on national systems. Member States clarified that authorisation was only required for treatment which was 'among the benefits provided for by the legislation in the Member State where the person concerned resides' (vector of treatment), and, if it could not be provided, 'within the time normally necessary for obtaining the treatment in question in the Member State of residence, taking account of his current state of health and the probable course of the disease' (vector of time). ${ }^{71}$

As amended, the Regulation now addresses two important reasons why patients would want to overcome territorial boundaries in the first place: quality of treatment (vector of treatment) and waiting times (vector of time). In the Pierik cases, the Court attempted to exercise auctorita perfecta with significant impact on the integrity of territorial boundaries,

\footnotetext{
${ }^{70}$ Case 117/77 Pierik (n 67) para 22.

${ }^{71}$ Council Regulation (EEC) No 2793/81 of 17 September 1981 amending Regulation (EEC) No 1408/71 on the application of social security schemes to employed persons and their families moving within the Community and Regulation (EEC) No 574/72 fixing the procedure for implementing Regulation (EEC) No 1408/71 art 22.2.
} 
which has far-reaching effects on the quantity of national solidarity. However, patients, who exit their health care system based on secondary legislation, were still required to request (prior) authorization under all circumstances. Thus, the principle of territoriality remained somewhat intact. However, the character of the original legal framework-based on secondary law - appears to have changed dramatically over the last 20 years or so due to a seismic intervention from the Court, by which it began to link health care with the free movement law of the Treaty. ${ }^{72}$

One of the early seminal cases, in which the Court introduced this approach, is Kohll. ${ }^{73}$ In this case, the Court brought health care under the umbrella of Article 56 TFEU, which prohibits 'restrictions on freedom to provide services within the Union'. With this move, the Court called the principle of territoriality, and consequently the integrity of territorial boundaries, into question. As the facts of the case are well known, I will recount them only briefly here. Mr Kohll's daughter, insured in Luxembourg, had received treatment from an orthodontist established in Germany. In line with both Luxembourg national law and also Article 22 Regulation 1408/71, now Article 20 Regulation 883/2004, Mr Kohll requested prior authorisation but was refused by the competent national authority.

The decision of the competent national institution was based on grounds that dental treatment for Kohll's daughter was neither urgent nor unavailable in Luxembourg. The Court subsequently found that the national law, which required prior authorisation, was in conflict with Article 56 TFEU because it constituted a restriction and was therefore in need of justification. ${ }^{74}$ The Court argued further that any restriction on medical or hospital services

\footnotetext{
${ }^{72}$ The EU legislator has adopted Directive 2011/24/EU of the European Parliament and of the Council of 9 March 2011 on the application of patients' rights in cross-border healthcare (OJ L88/2011) in order to 'achieve a more general, and also effective, application of principles developed by the Court of Justice on a case-by-case basis'.

${ }^{73}$ Kohll (n 14).

${ }^{74}$ ibid, para 54 .
} 
could only be justified if "the maintenance of a treatment facility or medical service on national territory is essential for the public health and even the survival of the population' ${ }^{75}$ The Court, however, could not find any such justification in this case. ${ }^{76}$

In his Opinion in Kohll, Advocate General Tesauro made reference to the possible effects EU health care law-based on free movement of services - had on national solidarity, dryly noting that ' $[\mathrm{t}]$ he only effect I can conceive of is that $[\ldots]$ [the] orthodontist established in the same State [Luxembourg] will have lost one patient. It is therefore the individual practitioners who are adversely affected and not the system itself ${ }^{77}$ The Court followed its Advocate General and added that 'it is clear that reimbursement of the costs of dental treatment provided in other Member States in accordance with the tariff of the State of insurance has no significant effect on the financing of the social security system'. ${ }^{78}$

By contrast and with regard to hospital care, the Court found that

[i]t is well known that the number of hospitals, their geographical distribution, the way in which they are organised and the facilities with which they are provided, and even the nature of the medical services which they are able to offer, are all matters for which planning must be possible. ${ }^{79}$

Thus the Court accepted, without the need for further detailed evidence, ${ }^{80}$ that the requirement of authorisation constitutes a necessary tool through which to not only control costs but also avoid wastage of resources. ${ }^{81}$ Similarly, in Geraets-Smits and Peerbooms, the ECJ held that the requirement of authorisation could be justified because it helps to guarantee the

\footnotetext{
75 ibid, para 51.

76 ibid, para 53.

77 Joined Opinion of AG Tesauro in Case C-120/95 Nicolas Decker v Caisse de Maladie des Employés Privés and Case C-158/96 Raymond Kohll v Union des caisses de maladie [1998] ECR I-01831, FN 90 (emphasis added).

${ }^{78}$ Kohll (n 14) para 42 (emphasis added).

${ }^{79}$ Case C-385/99, VG Müller-Fauré v Onderlinge Waarborgmaatschappij OZ Zorgverzekeringen UÀ and EEM van Riet v Onderlinge Waarborgmaatschappij ZAO Zorgverzekeringen [2003] ECR I-04509, para 77.

${ }^{80} \mathrm{cf}$ NN Shuibhne and M Maci, 'Proving Public Interest: The Growing Impact of Evidence in Free Movement Case Law’ (2013) 50 Common Market Law Review 965, 997-998.

${ }^{81}$ Müller-Faurè and Van Riet (n 78) para 80.
} 
preservation of 'a rationalised, stable, balanced and accessible supply of hospital services' ${ }^{82}$ The distinction between hospital and non-hospital care gained importance through this case and marked the watershed in the debate over whether a patient would require authorisation before overcoming territorial boundaries. ${ }^{83}$

Interestingly, in health care, the Court also acknowledged the need for an 'overall approach'. The judges considered it to be

self-evident that assuming the cost of one isolated case of treatment, carried out in a Member State other than that in which a particular person is insured with a sickness fund, can never make any significant impact on the financing of the social security system. ${ }^{84}$

This approach appears to be in contrast to the individualist strategy the Court originally pursued in cases such as Grzelczyk ${ }^{85}$ and in Baumbast, ${ }^{86}$ in which it developed the doctrine of the 'unreasonable burden'. The obvious criticism levelled against the Court was that the micro-level findings were inappropriately scaled up to the macro-level: 'one Baumbast and one Grzelczyk cannot really constitute an unreasonable burden upon the public purse - but ten-thousand Baumbasts and ten-thousand Grzelczyks might well have some more appreciable effect on the welfare resources of the host state' ${ }^{87}$

With Watts $^{88}$ the Court's case law on the cross-border movement of patients finally also reached the English National Health Service (NHS), which is tax funded and delivers its

\footnotetext{
${ }^{82}$ Case C-157/99, BSM Geraets-Smits v Stichting Ziekenfonds VGZ and HTM Peerbooms v Stichting CZ Groep Zorgverzekeringen [2001] ECR I-05473, para 81.

${ }^{83}$ CM Rieder, 'Cross-border Movement of Patients in the EU: A Re-Appraisal' (2017) 24 The European Journal of Health Economics 390, 411.

${ }^{84}$ Müller-Fauré and van Riet (n 78) para 74.

${ }^{85}$ Case C-413/99 Baumbast and $R v$ Secretary of State for the Home Department [2002] ECR I-07091, para 92.

${ }^{86}$ Case C-184/99 Rudy Grzelczyk v Centre public d'aide sociale d'Ottignies-Louvain-la-Neuve [2001] ECR I06193 , para 44.

${ }^{87}$ M Dougan and E Spaventa, 'Educating Rudy and the non-English Patient: A Double Bill on Residency Rights under Article 18 EC' 28 (2003) European Law Review 699, 707.

${ }^{88}$ Case C-372/04 Yvonne Watts v Bedford Primary Care Trust and Secretary of State for Health [2006] ECR I04325. The case involved an English patient who jumped the NHS waiting lists and went to France in order to receive a hip replacement.
} 
services free of charge at the point of use. ${ }^{89}$ The Court clarified that no public health care system, no matter how it is organised, escapes the application of free movement law. In order to trigger Article 56 of the TFEU, the Court had to construct an argument that services are provided for 'remuneration'. The Court, in its legal reasoning in Watts, focussed exclusively on the cross-border dimension of the transaction, that is, on the fact that a patient pays a health care provider directly in another Member State and is then reimbursed by the system of affiliation..$^{90}$ With this focus on the private transaction, the Court concluded that there was no need in the case of Watts 'to determine whether the provision of hospital treatment in the context of a national health service such as the NHS is in itself a service within the meaning of those provisions'. ${ }^{91}$ Reviewing that decision, Spaventa accused the Court of performing a 'hermeneutic "trick" .92

Be that as it may, at the fulcrum of the debate are opportunity costs, which critics argue have been overlooked by the Court in its case law. ${ }^{93}$ Opportunity costs follow from the fact that '[g]iven that resources_-including time - are limited, deciding to use a resource for one purpose forecloses opportunities for alternative uses' ${ }^{94}$ In the context of health care, the problem of opportunity costs presents itself in the following way. If one person is allowed to exit and receive expensive treatment, which was not catered for originally, in another Member State, then other patients who are further down the waiting list, which is organised in accordance with national criteria, will have their treatment delayed or, depending on the state

\footnotetext{
${ }^{89}$ On the organisation of the NHS, see C Newdick, Who Should We Treat? Rights, Rationing, and Resources in the NHS (2nd edn, OUP 2005) ch 4.

${ }^{90} \mathrm{cf} \mathrm{W}$ Gekiere, R Baeten and W Palm, 'Free Movement of Services in the EU and Health Care', in E Mossialos and others (eds), Health Systems Governance in Europe: The Role of European Union Law and Policy (CUP 2010) 461, 467.

${ }^{91}$ Watts (n 87) para 91.

${ }^{92}$ E Spaventa, Free Movement of Persons in the European Union: Barriers to Movement in Their Constitutional Context (Kluwer Law International 2008) 56.

${ }^{93}$ C Newdick, 'Preserving Social Citizenship in Health Care Markets: There May Be Trouble Ahead' (2008) 2 McGill Journal of Law and Health 93, 99.

${ }^{94}$ A Buchanan, Justice and Health Care. Selected Essays (OUP 2009) 39.
} 
of funding, will not receive a particular treatment at all. This will be the case unless the Member State is prepared to increase the funding and consequently the quantity of solidarity.

Admittedly, this argument would have some force if the Court's case law had the effect of increasing the quantity of national solidarity needed, which I argue is not the case. The gist of my argument based on authority is expressed in the Müller-Faurè and Van Riet case, where the Court held that the 'achievement of the fundamental freedoms guaranteed by the Treaty inevitably requires Member States to make some adjustments to their national systems of social security. It does not follow that this would undermine their sovereign powers in this field' ${ }^{95}$ I think the Court is correct in singling out 'powers' here. My point is that the Court's interpretation of free movement law does not require changes to the quantity of solidarity, thus ruling out opportunity costs in relation to solidarity.

Finally, I want to examine whether the application of EU citizenship alters the interpretation of free movement rights. ${ }^{96}$ In this context, the education case Schwarz is of interest. ${ }^{97}$ The case is particularly useful because it consists of similar structural components as the health care cases I have discussed thus far. Note that for the purposes of this article, I am not interested in the membership dimension of citizenship. Although my focus remains firmly on the effect of supranational law on the permeability of territorial boundaries, the question I explore is whether citizenship influences this relationship. In Schwarz, the issue was tax relief of fees for parents who send their children to a private school. In particular, the question was whether Germany would be in breach of EU law by refusing to grant the same tax relief for school fees incurred when a child is sent to a private school in a different Member State.

\footnotetext{
${ }^{95}$ Müller-Faurè and Van Riet (n 78) para 102 (emphasis added).

${ }^{96}$ I owe this point and case reference an anonymous reviewer from the Transnational Legal Theory.

${ }^{97}$ Case C-76/05 Herbert Schwarz and Marga Gootjes-Schwarz v Finanzamt Bergisch Gladbach [2007] ECR I06849.
} 
The German Government argued that because the fees for private schools in other Member States were higher than those for private schools in Germany, this would amount to an 'unreasonable burden' ${ }^{98}$ In its submission, the German Government made reference to the case of Bidar, which the Court developed the 'unreasonable burden' argument. ${ }^{99}$ Advocate General Stix-Hackl was of the opinion that free movement law and national solidarity are based on conflicting interests. ${ }^{100}$ The Court, on the other hand, argued that 'it is legitimate for a Member State to limit the amount deductible in respect of school fees to a given level'. ${ }^{101}$ This finding seems to be in line with the approach of the Court as outlined above.

The Schwarz case is interesting for two reasons. First, it provides an example in which the principle of Pareto efficiency was applied outside the context of cross-border movement of patients. Second, Schwarz makes reference to EU citizenship. In addition, the Court in Schwarz also clarified, almost as an afterthought, that whether one draws on free movement of services or, if not applicable, EU citizenship does not make any difference to the outcome of the case. There exists a parallelism from which it follows that

where taxpayers of a Member State send their children to school at a school established in another Member State, the services of which are not covered by Article 49 EC [now Article 56 TFEU], Article 18 EC [now Article 21 TFEU] precludes legislation which allows taxpayers to claim as special expenses conferring a right to a reduction in income tax the payment of school fees to certain private schools established in national territory, but generally excludes that possibility in relation to school fees paid to a private school established in another Member State. ${ }^{102}$

In this section I sought to conceptualise cross-border movement of patients based on the principle of Pareto efficiency, which by its nature conveys authority without the power to

\footnotetext{
98 ibid, para 59.

${ }^{99}$ Case C-209/03 R (on the application of D Bidar) v London Borough of Ealing and Secretary of State for Education and Skills [2005] ECR I-2119, para 56.

100 Opinion of AG Stix-Hackl in Case C-76/05 Schwarz [2007] ECR I-06849, para 39.

101 Schwarz (n 96) para 80.

102 ibid, para 99.
} 
change existing obligations (auctorita imperfecta). Based on the type of authority involved I argued that free movement rights take the form of Hohfeldian claim rights which do not have the power to change existing solidarity prescribed by the social contract. Moreover, the application of EU citizenship, so the case law has shown, has no more far-reaching effects if applied in relation to territorial boundaries which is in line with the theoretical argument of auctorita imperfecta developed in this article. In conclusion, the impact of supranational law on territorial boundaries, based on the principle of efficiency, can be described as modest at best. Our focus now shifts to the question of whether human rights and EU citizenship, based on the principle of dignity, have a more revolutionary effect on territorial boundaries.

\section{Dignity}

While welfare undoubtedly has an economic dimension, which has been the focus of our discussion so far, it also has another, moral, dimension. Michael Sandel made the point that 'market reasoning [. . . empties public life of moral argument'. ${ }^{103}$ Drawing on dignity as a principle in the context of health appears apt because both are intimately interconnected. ${ }^{104}$ This interconnectedness may be a consequence of the fact that dignity is related to vulnerability: we are in need of dignity because human beings are vulnerable. ${ }^{105}$ Before exploring this concept more thoroughly, it will be necessary to examine the meaning of

\footnotetext{
${ }^{103}$ MJ Sandel, What Money Can't Buy. The Moral Limits of Markets (Penguin 2012) 14 (emphasis added). ${ }^{104}$ KG Young, Constituting Economic and Social Rights (OUP 2012) 33.

${ }^{105}$ C Sedmak, 'Human Dignity, Interiority, and Poverty', in C McCrudden (ed), Understanding Human Dignity (OUP 2014) 566.
} 
dignity, which for Schlink amounts to nothing more than 'a Sehnsuchtsbegriff, a concept that encompasses our longing for a better and fairer world' ${ }^{106}$

We find references to dignity in a variety of legal documents such as the United Nations Declaration of Human Rights and the German Basic Law. ${ }^{107}$ More recently, dignity has also become a visible feature of European integration through the EU Charter on Fundamental Rights, Article 1 of which states that 'Human dignity is inviolable. It must be respected and protected.' Dignity, 'in its concern with status and stature has to do with the proper recognition of identity of every human being'. ${ }^{108}$ Thus, it is not without irony that the introduction of dignity in the EU context took place in reverse chronological order: recognition came for 'economic identity first and human identity last'. ${ }^{109}$ Be that as it may, Dupré argues that the introduction of dignity on the EU level 'could potentially have a very far-reaching transformative effect on EU law and its approach to human rights under the Lisbon Treaty'. ${ }^{110}$

In many ways, the relationship between health care and human rights is obvious. ${ }^{111}$ In addition, human rights have a twofold interconnectedness with dignity: ${ }^{12}$ there is the right to dignity but also the principle of dignity. ${ }^{113}$ In the following debate my focus is not on the right to dignity but rather on dignity as a principle. Moreover, I will discuss the interrelationship

\footnotetext{
${ }^{106}$ B Schlink, 'The Concept of Human Dignity' in C McCrudden (ed), Understanding Human Dignity (OUP 2014) 631, 634.

${ }^{107}$ M Rosen, Dignity: Its History and Meaning (Harvard UP 2012) 2.

${ }^{108}$ G Kateb, Human Dignity (The Belknap Press 2014) 12-13.

${ }^{109}$ C Dupré, 'Human Dignity in Europe: A Foundational Constitutional Principle' (2013) 19 European Public Law 319, 331.

110 cf C Dupré, 'Article 1 - Dignity' in S Peers and others (eds), The EU Charter of Fundamental Rights: A Commentary (Hart/Beck 2014) 01.25.

${ }^{111}$ For a more detailed account on international law, human rights and health, see T Murphy, Health and Human Rights (Hart 2013) ch 1.

112 J Tasioulas, 'Human Dignity and the Foundations of Human Rights' in C McCrudden (ed), Understanding Human Dignity (OUP 2014) 291.

${ }^{113}$ Waldron (n 50) 13 (emphasis added).
} 
between dignity and citizenship, ${ }^{114}$ which follows from the definition of dignity that I will present subsequently. Inevitably, the conceptualisation in this article will now take a more speculative turn because to date the Court has not examined cross-border movement of patients in the light of human rights or citizenship. ${ }^{115}$

A notable exception is the case of Stamatelaki, in which Advocate General Colomer made a brief reference to citizenship and human rights. ${ }^{116} \mathrm{Mr}$ Stamatelaki, who suffered from bladder cancer, was (publicly) insured in Greece but had received treatment on two occasions in the UK in a private hospital. When Mr Stamatelaki asked for reimbursement from Greek public funds, his request was denied because his treatment in the UK had been performed in a private hospital. While the Court resolved the case conservatively by adopting its classic free movement approach, ${ }^{117}$ the Advocate General flirted briefly with the idea of applying human rights in the context of cross-border movement of patients by referring to Article 35 of the EU Charter. ${ }^{118}$

Arguably, labelling something a 'human right' indicates its 'importance'. ${ }^{119}$ Human rights provide new vocabularies with which people can make their claims. ${ }^{120}$ This may have further implications for the possibility of law-making because, as Primus points out for the United States, although the finding applies beyond its borders, 'the associated language of human rights has become standard political rhetoric'. ${ }^{121}$ While Advocate General Colomer acknowledged in his Opinion that 'the case-law takes as the main point of reference the

\footnotetext{
114 cf Waldron (n 52) 333.

${ }^{115}$ See CM Rieder, 'Application and Interpretation of the EU Charter in the Context of Cross-Border Movement of Patients' (2016) 22 Columbia Journal of European Law 451.

116 AG Colomer in Stamatelaki (n 53) para 40.

${ }^{117}$ Case C-444/05 Aikaterini Stamatelaki v NPDD Organismos Asfaliseos Eleftheron Epangelmation (OAEE). [2007] ECR I-03185, paras 14-38.

118 'Everyone has the right of access to preventive health care and the right to benefit from medical treatment under the conditions established by national laws and practices. A high level of human health protection shall be ensured in the definition and implementation of all Union policies and activities.'

119 A Sen, 'Human Rights and the Limits of Law' (2006) 27 Cardozzo Law Review 2913, 2921.

${ }^{120}$ S Benhabib, Dignity in Adversity. Human Rights in Troubled Times (Polity 2011) 15

${ }^{121}$ RA Primus, The American Language of Rights (CUP 1999) 195.
} 
fundamental freedoms established in the Treaty', ${ }^{122}$ he subsequently expressed the more radical view that

there is another aspect which is becoming more and more important in the Community sphere, namely the right of citizens to health care, proclaimed in Article 35 of the Charter of Fundamental Rights of the European Union since, "being a fundamental asset, health cannot be considered solely in terms of social expenditure and latent economic difficulties". ${ }^{123}$

The Advocate General makes a deontological argument which is in contrast to the consequentialist approach outlined in the previous section. It is not unusual to bring together deontology and dignity, even if doings so remains controversial. ${ }^{124}$ The German Air Safety Law provides an example of this. In this context the German Constitutional Court considered the question of whether the shooting down of passenger planes, if hijacked, is a legitimate course of action. The Bundesverfassungsgericht held that '[s]uch a treatment [shooting down a plane] ignores the status of the persons affected as subjects endowed with dignity and inalienable rights. By their killing being used as a means to save others, they are treated as objects'. ${ }^{125}$ I would argue that in his opinion on Stamatelaki, Advocate General Colomer makes a similar point against the objectification of patients when they are considered as mere cost-factors. The problem with this approach, however, is that it does not explain how we should balance the dignity of patients with potentially fatal illnesses. ${ }^{126}$

In my view, linking dignity with the idea(l) of deontology, while noble in its objective, is not a promising approach. And thus, the question of what constitutes the gist of the principle of dignity, which is a difficult concept, ${ }^{127}$ needs to be to be addressed. Waldron, who has made an elaborate attempt to interpret the meaning of dignity by tracing its historical

\footnotetext{
122 Opinion of AG Colomer (n 53) para 40.

123 ibid.

${ }^{124}$ Rosen (n 106) 104-119.

${ }^{125}$ BVerfGE, 115, 118 [154] M Rosen tr (n 106) 106.

${ }^{126}$ Rosen (n 106) 108.

${ }^{127}$ M Dan-Cohen, 'Introduction' in J Waldron, Dignity, Rank, and Rights (OUP 2015) 3.
} 
roots, reminds us that in the Roman context, dignitas was derived from honour, privileges but also rank. In this conception, dignity and rank, which is hierarchical in nature, are not mutually exclusive, because 'within each rank, everything is equal'. ${ }^{128}$

Based on these preliminaries, Waldron hypothesises that 'the modern notion of human dignity involves an upwards equalization of rank, so that we now try to accord to every human being something of the dignity, rank, and expectation of respect that was formerly accorded to nobility'. ${ }^{129}$ To illustrate his point, Waldron compares the circumstances of war under which only the nobles, that is the knights, were treated with dignity when captured on the battlefield by the enemies, whereas modern laws of warfare aim to expand the same rank to all the soldiers on the battlefield by giving them equal status. ${ }^{130}$ In other words, the principle of dignity is protected through law.

Before considering its implications for the concept of dignity, Waldron's hypothesis requires closer examination. I want to begin by analysing the question in more depth also what is to be understood by 'equalization' but also what is the meaning of 'rank'. Let me begin my discussion by analysing the meaning of "equalization" in relation to dignity. Towards this end, it is helpful to distinguish between "basic equality" and "surface-level equality". This distinction also features prominently in Dworkin's work on equality. ${ }^{131}$ The principle of basic equality demands that a government shows both 'equal concern for the fate of all' and 'full respect for personal responsibility' ${ }^{132}$ Elaborating on this point, Dworkin employs the example of buying health insurance.

\footnotetext{
${ }^{128}$ J Waldron, Dignity, Rank, and Rights (OUP 2015) 32.

129 ibid 33 (emphasis added).

130 ibid 35.

131 J Waldron, One Another's Equals (Harvard UP 2017) 14-15.

${ }^{132}$ R Dworkin, Justice for Hedgehogs (Harvard UP 2011) 338.
} 
People who wish to purchase a policy will have to decide for themselves how much money they consider prudent to spend on health care. If they decide to go for full comprehensive coverage, the cost of their policy will be very high, which will significantly limit what else they can afford while they are still healthy. It is therefore likely that they will apply the 'prudent insurance' principle, as Dworkin calls it, which

balances the anticipated value of medical treatment against other goods and risks: it supposes that people might think they lead better lives overall when they invest less in doubtful medicine and more in making life successful or enjoyable, or in protecting themselves against other risks, including economic ones, that might also blight their lives. ${ }^{133}$

And yet, taking basic equality seriously does not rule out surface-level inequality among people. ${ }^{134}$

That said, showing basic equality for all does not necessarily prevent surface-level inequality. Take as an example a job advertisement calling for firefighters which limits applicants to people under a certain age. One could argue that this amounts to a form of surface-level inequality. However, attracting firefighters who are sufficiently young in order to fulfil the duties of this physically demanding job benefits the old and the young in their basic equality. ${ }^{135}$ This means that the surface-level inequality nevertheless takes the interests of the old and young equally seriously (i.e. consistent with basic equality). This relationship between basic equality and surface level inequality played an important role in the reasoning adopted by the German Bundesverfassungsgerichtshof in the Nikolaus-Beschluss, ${ }^{136}$ albeit in the reverse.

\footnotetext{
${ }^{133}$ R Dworkin, Sovereign Virtue. The Theory and Practice of Equality (Harvard UP 2002) 316-317.

${ }^{134}$ Waldron (n 130) 13.

135 ibid 14.

${ }^{136}$ BVerfGE 115, 25.
} 
In this case, a young boy was suffering from Duchenne muscular dystrophy, a lifethreatening illness. No scientifically-tested treatment existed at the time and the competent national authority denied the request for an alternative treatment. The Court's decision was based on the relevant legal provisions from the German Social Security Code, which calls for economic efficiency. The German Federal Government argued that ignoring the efficiency principle because of limited resources, would endanger the stability of the entire health care system. ${ }^{137}$ The Bundesverfassungsgericht stated that in Germany, public health insurance is based on the principle of mandatory insurance ('Pflichtversicherung'), the purpose of which is to provide an affordable health care system for everyone. ${ }^{138}$ The US, by contrast, is a prime example of what happens to the cost of health care when it is privatised. ${ }^{139}$

The German Constitutional Court acknowledged that the mandatory integration of people into a system deprives them of choices. ${ }^{140}$ While this does not necessarily undermine their basic equality, since it takes equal consideration of competing interests, it nevertheless will have implications for the justification of surface-level inequality. Based on the above considerations, the German Constitutional Court rightly concluded that a health care fund is required to pay for a patient's treatment provided that a patient has at least some chance of healing ('nicht ganz fern liegende Aussicht auf Heilung') and/or a noticeable positive influence on the disease is achievable ('spürbare positive Einwirkung auf den Krankheitsverlauf'). ${ }^{141}$ The Constitutional Court appears to argue that the mandatory integration into the system influences what a person can claim. ${ }^{142}$ The point can be made that,

\footnotetext{
137 ibid $37-38$.

138 ibid 44

139 Dworkin (n 133) 307.

140 BVerfGE 115, 25 [42].

141 ibid [49].

142 ibid [42-42].
} 
surface-level inequalities are only justified if they do not 'discriminate in the range of human interests that we cater to when we make this justification'. ${ }^{143}$

I now want to turn to the second parameter which features prominently in Waldron's interpretation of dignity, namely rank. But what do we mean by "rank"? Waldron hints at an answer when he argues that 'the dignity of the citizen perhaps represents one possible realization of human dignity'. ${ }^{144}$ According to Waldron, when we speak of citizenship of the world and human dignity, the boundaries between the two concepts begin to 'blur'. ${ }^{145}$ An argument can further be made that it makes a significant difference for national welfare systems whether national citizenship is the reference point for dignity or supranational citizenship.

If, for example, national citizenship remains the rank which is our reference point for equalization, then it seems plausible to argue, especially in the context of the EU, that the only evolutionary effect of dignity will be on the permeability of territorial boundaries. The situation is, however, entirely different if EU citizenship is our reference point, in which case territorial boundaries would need to become more permeable in order to meet the requirement of dignity. This would be so, because it would no longer be justifiable that, for example, people from Romania receive much different treatment than people from people from Germany with the same health care needs. However, the answer to the question whether national citizenship or EU citizenship is our reference point is normative.

The last word goes to authority. The point has been made that dignity requires that people of the same "rank" are to be treated as equals. To achieve this goal, we need to rely on power rights, which convey the authority to alter existing obligations. Basic equality does not

\footnotetext{
${ }^{143}$ Waldron (n 131)14.

144 Waldron (n 53) 336.

145 ibid.
} 
permit for surface-level inequality if it is based solely on existing boundaries. For the purposes of this article, it follows that we need rights, that is, human rights, which convey authority also to change the quantity of national solidarity. Altering the permeability of territorial boundaries would accommodate this, albeit with revolutionary effects on boundaries and solidarity.

\section{Conclusion}

In this article, I examined the impact supranational law, especially in the form of rights, has on the principle of territoriality and the integrity of territorial boundaries as well as its further implications for national solidarity. In particular, I argued that rights can convey different types of authority, and that which type is determined by the different principles involved. The principles I focused on were efficiency and dignity. With regard to authority, I distinguished between auctorita imperfecta, which constitutes authority without power, and auctorita perfecta, which conveys authority with power. To translate this type of authority into a form of rights, I applied Hohfeldian taxonomy, drawing a distinction between claim rights, which are related to auctorita imperfecta, and power rights, which are linked to auctorita perfecta. This categorisation has significance for the purposes of solidarity, because only power rights confer the authority, that is auctorita perfecta, to alter existing obligations such as solidarity. Thus, claim rights have evolutionary effects, whereas the effect of power rights on boundaries and subsequently solidarity can be revolutionary.

Next, I applied this theoretical framework to the cross-border movement of patients, a field in which territoriality is pivotal. I began by examining the forms of and authority 
associated with the right to free movement of services, which has played a significant role in cross-border movement of patients. In recognition of free movement rights, the Court began to remove the requirement of prior authorisation for patients who wanted to be treated in another Member State. I argued that woven through the case law of the Court, it is possible to identify the principle of Pareto efficiency, which by its nature is linked to auctorita imperfecta. With regard to the categorisation of rights, the right of free movement of services takes the form of claim rights which, I argued, do not have the authority to change the existing obligations of a (social) contract. This in turn means that they cannot alter the existing pool of (national) solidarity.

The article then examined whether rights, that is, human rights, based on the principle of dignity have a more significant impact on territorial boundaries than efficiency. In line with Waldron, I argued that dignity constitutes a status or rank which is protected by law. If this is the case and if dignity aims for an 'upwards equalization of rank', then to achieve this aim, rights must convey auctorita perfecta because equalization may require a change of existing obligations in a hypothetical social contract. Applying Hohfeldian taxonomy we seem to deal here with power rights, which have a potentially revolutionary impact on boundaries and solidarity. Whether they realise that potential depends on the interpretation of dignity, the principle on which they are based, which in turn is related to rank, as I have explained. Arguably, revolutionary results can only be expected if the rank in question operates at either the supranational-level or the global-level. This question, however, whether the supranationalor global-level is operative, is normative in nature and beyond the scope of this article. 